\title{
ACHIEVEMENT MOTIVATION OF SECONDARY SCHOOL STUDENTS IN RELATION TO THEIR SOCIAL POSITION IN THE CLASS
}

\author{
Ivana Poledňová, Zdenka Stránská \\ Masaryk University, Brno, Czech Republic \\ E-mail: polednov@fss.muni.cz, stranska@phil.muni.cz \\ Hana Niedobová \\ Primary School, Letovice, Czech Republic
}

\begin{abstract}
The study was based on a theoretical presumption that social climate and relationships in the class can be in specific ways connected with students' achievement motivation. Previous research in the area of student motivation was mostly based on self-reports and was therefore focused on explicit motives, i.e. personal goals which the respondents strived for. Self-report measures of motivation, however, can be affected by biases and misperceptions of one's own self. Our study approached achievement motivation at its implicit, i.e. non-conscious level. It was conducted with students in five classes of a secondary school, $N=138,107$ female and 31 male, with an average age of 17 years. The respondents were administered a sociometric questionnaire and the projective Thematic Apperception Test (TAT) in McClelland's adaptation using Heckhausen's content-analytical clue for the measurement of achievement motivation. The hypothesized relation between social position in class and achievement motivation was only partly supported. Affiliation was unrelated to achievement motivation, even when analyzed for both achievement motives separately. We found a slight negative relationship between influence in the class and achievement motivation, especially with the motive to achieve success. These results, partly diverging from theoretical presumptions, can be explained in terms of specific features of the sample as well as a general methodological disparity in previous research, especially a lack of differentiation between implicit and explicit motives in the interpretation of the findings.
\end{abstract}

Key words: achievement motivation, social position, sociometry.

\section{Introduction}

The issue of achievement motivation is still a relevant topic in psychology research. A socialpsychological perspective, which takes into account one's interactions in social relationships, reveals how these relationships assist in shaping the individual's achievement orientation. One may assume that achievement orientation of the student is not solely influenced by the teacher but is shaped by the overall classroom climate, including the student's social position in the class. Although there has been a great body of research concerning achievement motivation at school, in most cases, the studies focused on specific learning motivation, or on school performance, which is understood as a result of this motivation. Studies directly concerned with social position 
of the student in the class in relation to his/her general achievement motivation are very rare. For example, Pavelková (1997) argues that in the school environment, achievement motivation in the form of motivation for learning is formed through an intentional process of creating conditions in which pupils' learning activities have a positive incentive value. Throughout the school year, motivational dispositions should be developed not only in terms of quantity, but also in terms of quality, especially by being restructured in favour of internal motivation, which has the most positive impact on the quality of learning and also prepares ground for continuous motivation for learning as a lifelong endeavour to extend one's own knowledge. According to Hrabal jr. (1979), a child at school is subject to extensive assessment which determines the level of his abilities by comparing him to other children. The child is thus forced into a role of a good, average or underachieving student, which subsequently affects his motivation. This recurring experience of success and failure results in the development of "academic achievement needs", which, however, do not have to be in complete agreement with the student's general achievement orientation. Still, correct identification of the student's level of general achievement motivation is crucial when intervention regarding academic achievement orientation is required.

At the moment, achievement motivation is a very topical issue owing to today's society's focus on success. For a long time, the dominant theories of achievement motivation were those postulated by McClelland, Atkinson and Heckhausen (Wigfield \& Eccles, 2002), who understood achievement motivation as the resulting tendency of an emotional conflict between the motive of achieving success and the motive of avoiding failure. The core of both motivational tendencies is formed by two achievement needs (need of success and need of avoiding failure), which are independent of each other, i.e. they do not form a bipolar continuum in which the existence of one need excludes the effect of the other. In fact, these two needs may co-occur, and their joint effect determines the behavioural tendency in a particular achievement situation. These two basic motivational tendencies affect people's behaviour in various task situations, as well as their actual performance. Achievement motivation as a relatively stable disposition is an important factor of performance, including motivation for learning. According to Ward (1997), people with high achievement motivation are focused on achievement goals and are generally proactive. Murray (1938) postulated the need for achievement as a fundamental one in his taxonomy of needs.

\section{Research Problem}

Until today, research on student motivation at school relied almost exclusively on self-reports and the measurement of "explicit" motives, which are most likely to reflect the level of personal goals the individual strives for. However, this method of measurement often lacks objectivity because the results are biased by inaccurate self-perceptions. For this reason, our study focused directly on the implicit, i.e. non-conscious, aspect of achievement motivation.

The achievement motive belongs to the "Big Three" of implicit motives (together with affiliation and power motives), which are presumed to be unrepresented in consciousness and formed unconsciously (McClelland, 1995). It turns out that implicit motives are good predictors of free decisions, spontaneous behavior and long-term personal development (e.g. career) (e.g. Spangler, 1992; Schultheiss \& Brunstein, 2010). We assume that the assessment of implicit motives in student population might be helpful in evaluating the appropriateness of students' long-term goals and, if need be, encouraging effective change.

Achievement needs belong to higher needs, which are formed during the individual's life primarily on the grounds of social factors. Regarding the issue of influencing achievement motivation, scientific literature so far has placed much emphasis especially on the role of teachers, whereas the role of the class as a social group has been either neglected or mentioned only in connection with the teacher's instruction style. However, the overall classroom climate, and hence also the learner's position in the class, are crucial factors affecting all pupils' activities at school, including their achievement motivation. In accordance with the theory of achievement motivation, one can suppose that a good social position will increase achievement motivation. Yet, individual aspects of social position (influence and popularity) can be related to achievement motivation in different ways. Nevertheless, research on this topic is rather rare (e.g. Fitzgerald, 1958), and the 
relation between social position in the class and achievement motivation is thus worth further exploration.

\section{Research Focus}

The aim of the present study was to test whether students' social position in a secondary school class correlates with their level of achievement motivation. The research was based on the theoretical assumption that classroom climate and peer relationships in the class can affect or even increase achievement motivation. Both basic achievement needs - need for success and need for avoiding failure - are in an essential connection and interaction with the school environment, which determines achievement orientations of the students and is, in turn, also influenced by these orientations.

Previous research on achievement motivation and interpersonal relationships yielded rather inconsistent findings. This was apparently caused by different methodological approaches employed as well as different populations that served as sampling pools. Self-report data on the respondents' own conscious motives provide a subjective perspective of the causes of their own behaviour. The accuracy of these data is limited by the respondents' self-reflection abilities, and thus the results often provide a poor measure of implicit motivation, which forms primarily in early childhood and is not easily influenced by social factors later in life (Koestner et al., 1991). Hence, we designed the present study to explore this stable motivational aspect of personality in the context of social interactions.

\section{Research Method}

\section{General Method}

Social position in the class, derived from peer relations within the class, is something which all students reflect upon, as they are daily confronted with some form of social evaluation by their peers. Therefore, it is likely to impact the student's school experience, including his/her study behaviour and motivation. The present quantitative study was conducted on a sample of secondary school students. Social position in the class was defined by the dimensions of influence, popularity and affiliation. The study especially focused on implicit, i.e. non-conscious, achievement motivation. Generally, it was assumed that high social status would be associated with higher levels of achievement motivation.

\section{Participants}

The research was conducted with students in five classes of a secondary school, $N=138$, 107 female and 31 male. The number of students in each class ranged from 26 to 29 . The classes of upper-secondary level (second and third years of study) were chosen, as one could expect that at that point students had become sufficiently acquainted with their classmates, and class relationships had been established. The age of the respondents ranged from 16 to 19 years, with an average of 17 years.

\section{Instruments and Procedures}

The following research instruments were used:

1. The Sociometric Rating Questionnaire (SO-RA-D)

While the SO-RA-D can be ranked among sociometric measures, it is also closely related to rating procedures. In this measure, all students in the class rate each other with respect to popularity (tendency towards mutual encounter) and influence (how others follow their behaviour and opinions). The participants in our study obtained written instructions and a recording sheet in which they were asked to rate every other 
student in the class on a scale according to the student's popularity and influence. For the purpose of data analysis, two separate recording sheets were used in each class one for popularity and affiliation, and one for influence. The initial data analysis was conducted by means of sociometric matrixes, and the results were expressed quantitatively as indexes, computed as averages of all ratings of a particular person in the class. The popularity recording sheets obtained from all students altogether yielded the popularity index of each student in the class (how others evaluated him/her regarding his/her likeability). By averaging all popularity indexes, we acquired the total class popularity index. The set of ratings of others provided by each single student was used to calculate the student's own affiliation index (how positively they evaluated others). Finally, the influence recording sheets collected from all students yielded the influence indexes of their peers (how they were assessed by classmates concerning their participation on running the group). By averaging all the indexes of influence, we computed the total class influence index.

While the popularity index and the influence index are "objective" (i.e. arithmetic) ratings which the individual received from other group members, the affiliation index is the arithmetic mean of ratings provided by the individual regarding other group members (Hrabal, 1987).

\section{The Thematic Apperception Test (TAT)}

The test was first introduced by Murray and Morgan in 1935 as a method of revealing patients' hidden fantasies, based on the mechanism of projection (Murray, 1943). The original principle of the test was used in the 1950s at Harvard University by McClelland and his collaborators in order to measure achievement motivation. The TAT stories were assessed by means of content analysis, which served as a basis for McClelland's scoring system in the 1950s. In German-speaking countries, a similar test was used called Heckhausen's scoring system. In our study, we used verbal instructions derived from McClelland's scoring manual of the TAT worded in the following way: "We would like you to look at some pictures, one at a time. After you look at the pictures, please make up a story about what might be going on in the picture. Try to imagine what is happening. Then say what is going on now, what happened before, what people are thinking and feeling, and what they will do. Write a story that is complete - a story that has a beginning, a central plot, and an ending. There are no right or wrong pictures, so write whatever story you think of when you look at the picture. Spelling, punctuation and grammar are not at all important. To help you remember what to talk about in your stories, we have put some reminders at the top of each page. They will ask if you have mentioned:

What is happening? Who are the people?

What happened before?

What are the people thinking and feeling? What do they want?

What will happen next?

First look at the picture for about fifteen seconds. Then write your story, taking no more than five minutes. There is one page for writing each story. (McClelland, 2002; according to Smith et al., 2002, p. 538).

The pictures were presented using a slide projector. The participants were only shown four pictures from entire set of the TAT - those which were most closely related to the topic of achievement motivation (Figure 1):

Picture 1: A boy is looking pensively at a violin lying in front of him on the table.

Picture 2: Countryside scene: in the front, there is a young woman with a book in her hand; in the background, there is a man working in the field and an older woman standing by. 
Picture 7FG: An older woman is sitting on a sofa right next to a girl; she is talking to her Vol. 8, No. 1, 2014 or reading to her. The girl, who is holding a doll in her lap, is looking away.

Picture 8BM: An adolescent boy is in the foreground. On one side of the picture, one can see a rifle; at the back, there is an unclear scene of a surgery operation, similar to a dreamlike picture.

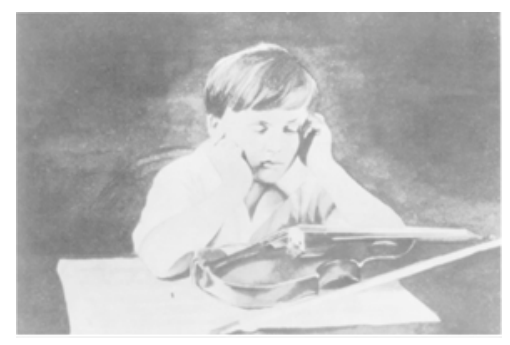

Picture 1

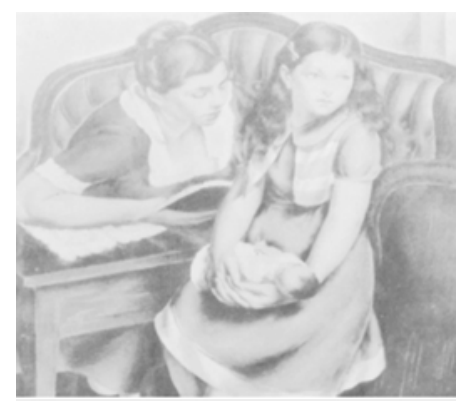

Picture $7 F G$

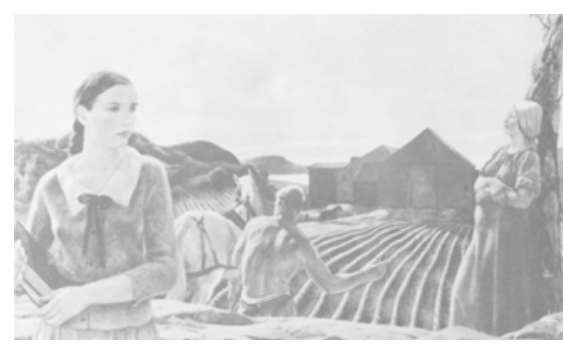

Picture 2

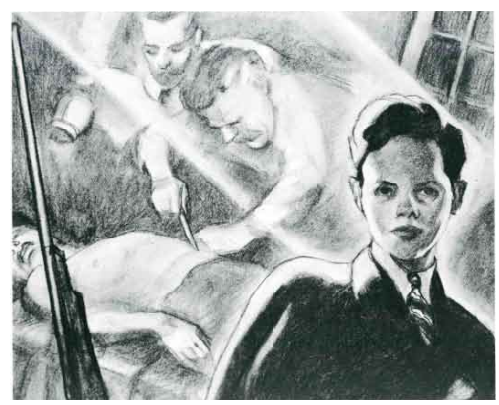

Picture $8 B M$

\section{Figure 1: Pictures from the TAT test used for research.}

The student participants wrote stories on the distributed sheets with follow-up questions. The obtained stories were scored using the German Heckhausen's key based on content analysis. Heckhausen (1980) gives a list of content categories; if they are present, a point is added for either hope for success or fear of failure:

\section{Hope for success:}

1. Need to achieve and succeed. In the story, somebody sets a positively formulated achievement goal or feels urged to achieve it.

2. Instrumental activity to achieve a goal.

3. Expecting success.

4. Praise for successful achievement.

5. Positive emotional state which is related to work, performance and successful achievement of a goal.

6. Topic of success as a semantic unit if the story has a prevailing content directed by success.

\section{Fear of failure:}

1. Need to avoid failure, e.g. by setting negatively formulated achievement goals; wishing something happened that could help us avoid failure; feeling sorry for having done something that resulted in failure; or hesitations and fear of the consequences of failure. 
2. Instrumental activity directed at avoiding failure.

3. Expecting failure.

4. Criticism and chastisement due to insufficient performance.

5. Negative emotional state which is related to work and achievement.

6. Failure, if actions regarding achievement end up in failure.

7. Topic of failure as a semantic unit if the story has a prevailing content controlled by failure.

For every student, we added up, separately for each picture and then together for all four pictures, the number of categories related to the hope for success, obtaining the total index of the achieving success motive. In the same way, we added up the number of categories related to the fear of failure, obtaining the total index of the avoiding failure motive. By adding up both motives, the total index of overall achievement motivation was computed.

\section{Hypotheses}

In relation to the theoretical points of departure and the research instruments used, the following hypotheses were formulated:

H1: Students' achievement motivation increases with higher influence in the class.

H1a. Influential students in the class are more motivated to achieve success.

H1b. Students with low influence are more motivated to avoid failure.

H2: Students' achievement motivation decreases with higher popularity in the class. H2a. Popular students in the class are less motivated to achieve success.

H2b. Students with low popularity in the class are more motivated to avoid failure.

H3: Students' affiliation in the class is not related to their achievement motivation. H3a., H3b. Students with high affiliation in the class are not motivated either to achieve success or to avoid failure.

H4: Students with a high position in the class with respect to influence and popularity are more motivated towards achievement than students with an average position, who are more motivated than students with an inferior position.

\section{Statistical Analysis}

Research hypotheses were tested statistically. The variables entered into the analysis included the SO-RA-D indexes - index of influence, index of popularity and index of affiliation - and achievement indexes from the TAT test - total index of overall achievement motivation, total index of the achieving success motive and total index of the avoiding failure motive. To verify hypotheses H1 - H3 and partial subhypotheses, the nonparametric Spearman's rho correlation coefficient was used. In order to test the hypothesis H4, we first divided the students into groups, creating a new variable position level. The participants were divided into subgroups according to their popularity (high/low) and influence (high/low). In the final stage, we worked with three subgroups - students with high influence and high popularity, students with low influence and low popularity, and a remaining group regarded as students with average influence and average popularity. H4 was tested by comparing the means of achievement motivation in the given subgroups using a Kruskal-Wallis test. 
The results are presented separately for each hypothesis.

H1:

The correlation between influence in the class and achievement motivation measured by the TAT was low to medium and negative (Spearman's rho $=-0.21, \mathrm{p}=0.015$ ). The identified correlation between the two variables was significant, yet not in the anticipated direction - hence, H1 was not supported. It was evident that with a growing influence in the class, achievement motivation slightly declined (see Figure 2). A more detailed analysis of the correlation between influence and both achievement motives also revealed a low to medium negative correlation between influence and the achieving success motive (Spearman's rho $=-0.18$ ), significant at the level of $p=0.03$. Thus, H1a was not supported either due to the acquired direction of the correlation, i.e. with a growing influence, the motive of achieving success slightly declined. The correlation between influence and motive of avoiding failure was statistically insignificant.

These results can be interpreted in the context of theoretical presumptions of achievement motivation. It seems that if students have considerable influence in class, they tend to be less motivated to achieve success and improve their position, as they are content with their influential position, and thus there is no other need that has to be satisfied in order to restore equilibrium.

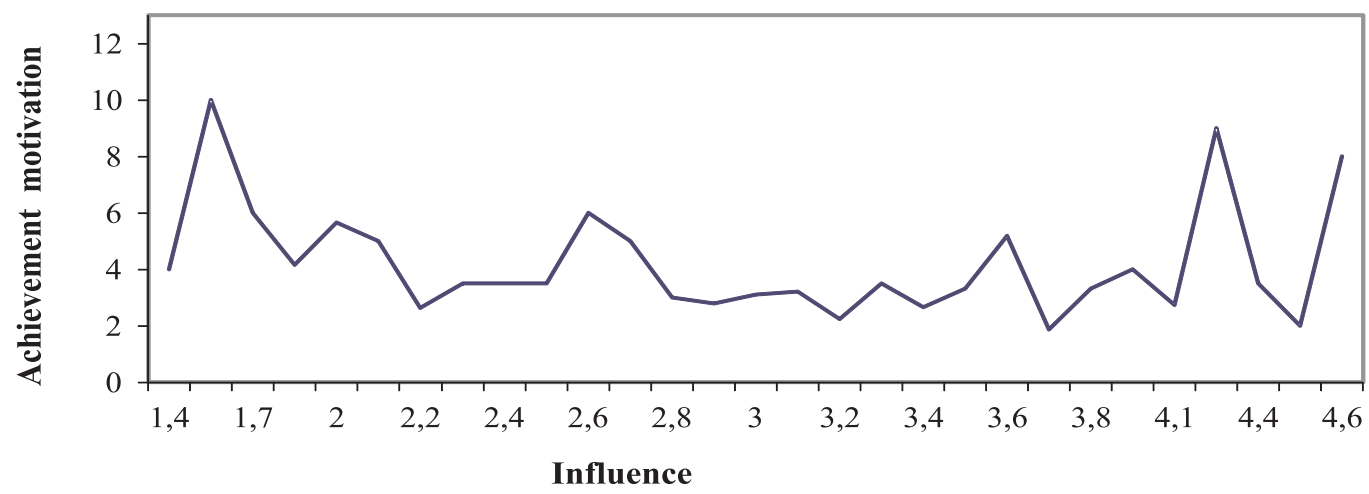

\section{Figure 2: Line graph showing the relationship between TAT achievement motivation and influence.}

$\mathrm{H} 2$ :

The correlation between popularity and achievement motivation measured by the TAT was low to medium (Spearman's Rho= -0.12) and non-significant. A more detailed analysis showed that the correlations between popularity and the achieving success motive as well as the avoiding failure motive were also non-significant.

\section{H3:}

The correlation analysis also showed that affiliation and achievement motivation as measured by the TAT were unrelated, which means that $\mathrm{H} 3$ was supported (see Figure 3). This was also true for both partial sub-hypotheses - neither of the two components of achievement motivation was significantly related to affiliation. 


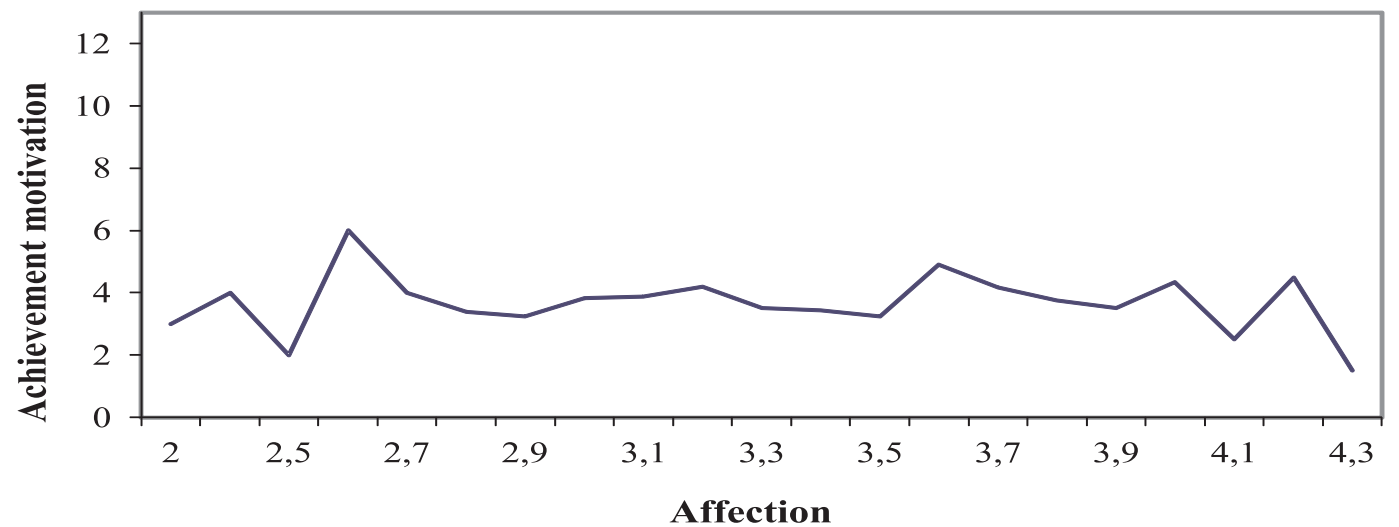

Figure 3: Line graph showing the relationship between TAT achievement motivation and affection.

H4:

Differences between achievement motivation scores of students with different social positions in the class (as given by the combination of influence and popularity) proved non-significant (see Table 1).

\section{Table 1. Comparison of levels of position according to the total index of} overall achievement motivation.

\begin{tabular}{cccc}
\hline & $\begin{array}{c}\text { Number of } \\
\text { persons }\end{array}$ & $\begin{array}{c}\text { Mean of total } \\
\text { achievement } \\
\text { motivation }\end{array}$ & $\begin{array}{c}\text { Standard } \\
\text { deviation }\end{array}$ \\
\hline $\begin{array}{c}\text { High position } \\
\text { (high influence and high popularity) } \\
\text { Average position } \\
\begin{array}{c}\text { Inferior position } \\
\text { (low influence and low popularity) }\end{array}\end{array}$ Total $^{21}$ & 3.5 & 3.2 \\
\hline
\end{tabular}

\section{Discussion}

The TAT provided us with a measure of implicit achievement motivation with good construct validity. Heckhausen, in his description of the TAT, concludes that "finally, individual differences in motives could be measured with standardized stimulus material, which means that the action meets the validity criterion and has been successfully tested in many studies, in which motive indicators substantially contributed to the variance in different behaviours and experience." (Heckhausen, 1980, p. 257).

In the present study, the total achievement motive scores in the TAT were generally low, with one part of the sample obtaining 0 points in all four stories. Furthermore, there was a substantial difference in the values of individual aspects of the achievement motive in those respondents who scored high in the achievement motive as compared with those who scored low. This means that if the achievement motive was actually present, the respondent most probably obtained very different scores in the individual motivational categories. This demonstrates that achievement motivation is a differentiated construct with individual aspects forming patterns of relationships which may vary widely.

Overall, it can be concluded that the study brought support for one third of our hypotheses as a response to our research question. Out of the original six hypotheses, only two were supported. In addition, one of the observed correlations was in a direction opposite to that which was hypothesized. The reformulated Hypothesis 1 was based on previous fragmentary research findings; 
however, the present results are in greater accordance with the assumed principles of achievement motivation. Thus, in general, it was only partially confirmed that achievement motivation might be associated with the student's social position in a secondary school class.

The main finding of the study was that students who occupy better positions in the class in terms of popularity or influence are not too highly motivated towards achievement, especially towards achieving further success, seems to be in contradiction to the postulates of the achievement motivation theory. In contrast to, for example, Lokšová and Lokša (1999), high status of the student in the class, perceived either as a combination of influence and popularity or as each of them separately, did not have a positive effect on achievement motivation. Moreover, the relationship of achievement motivation to social position in our study was much weaker than the one reported by e.g. Pilkiewitz (1991).

There are several possible explanations of this finding. First, specific features of our sample might have affected the results. The study was conducted in a secondary school environment, where the effect of social relations and status manifests differently than at primary school (e.g. the class establishes different social norms). Similarly, it is possible that the effect of classroom climate on achievement motivation might nonetheless to a greater extent consist in the teacher's influence rather than peer interactions. Our main assumption, however, is that previous research did not clearly differentiate between explicit and implicit motives. Although the association between the two is still unclear, various authors view them as largely independent constructs (Brunstein et al., 1998, McClelland et al., 1989, etc.), or report very weak correlations (e.g. Elliot \& Thrash, 2002).

Concerning students' feedback on the study and data collection, there were numerous complaints that if the students put their names on the SO-RA-D questionnaire, the responding could not be considered anonymous. They had to be assured that despite this initial need of identification, all data concerning themselves would be processed anonymously. Also, many students found the TAT pictures dated and often asked if there were any colour pictures coming. The group administration was generally more time-consuming, as group dynamics in the class had to be taken into account. The content analysis of 552 stories generated in response to the TAT tables was very demanding in terms of both time and energy, which might have affected assessors' objectivity. Despite this general arduousness, however, we believe that the use of projective techniques is advisable in further research as well.

\section{Conclusions}

The research yielded only partial evidence for the idea that social position in the secondary school class might affect the student's achievement motivation. However, the study revealed some previously unobserved correlations between partial aspects of social position and achievement motivation.

Specifically, with growing influence of the students in the class, their achievement motivation slightly declined. When achievement motivation was represented as two separate achievement motives, we found that higher influence in the class was related to slightly decreased levels of motive of achieving success.

Regarding student affiliation, it was found that affiliation operationalized as an overall subjective rating of one's classmates, was unrelated to both overall achievement motivation and the separate motives of achieving success and avoiding failure. Students' popularity in the class was also unrelated to achievement motivation. No evidence was found either for the assumption that students with a high social position as determined by both influence and popularity are more motivated towards achievement than students with an average or inferior position.

\section{References}

Brunstein, J. C., Schultheiss, O. C., \& Grässmann, R. (1998). Personal goals and emotional well-being: The moderating role of motive dispositions. Journal of Personality and Social Psychology, 75, 494-508.

Elliot, A. J., \& Thrash, T. M. (2002). Approach-avoidance motivation in personality: Approach and avoidance temperaments and goals. Journal of Personality and Social Psychology, 82 (5), 804-818. 
Ivana POLEDŇOVÁ, Zdenka STRÁNSKÁ, Hana NIEDOBOVÁ. Achievement Motivation of Secondary School Students in Relation to their Social Position in the Class

Fitzgerald, B. J. (1958). Some relationships among projective test, interview, and sociometric measures of dependent behavior. The Journal of Abnormal and Social Psychology, 56 (2), 199-203.

Heckhausen, H. (1980). Motivation und Handeln. Berlin, GE: Springerverlag.

Hrabal jr., V. (1979). Motivace a školní úspěšnost žáků. In Helus, Z., Hrabal jr., V., Kulič, V., \& Mareš, J., Psychologie školní úspěšnosti žáků (pp. 61 - 110). Praha: SPN. [Motivation and school success of students. In Psychology of pupils'school success].

Hrabal, V. (1987). SO-RA-D (Sociometrický ratingový dotazník). Bratislava: Psychodiagnostické a didaktické testy, [SO-RA-D (Sociometric rating questionnaire)].

Koestner, R., Weinberger, J., \& McClelland, D. C. (1991). Task-intrinsic and social-extrinsic sources of arousal for motives assessed in fantasy and self-report. Journal of Personality, 59, 57-82.

Lokšová, I., \& Lokša, J. (1999). Pozornost, motivace, relaxace a tvořivost dětí ve škole. Praha: Portál. [Attention, motivation, relaxation and creativity of children in school].

McClelland, D. C., Koestner, R., \& Weinberger, J. (1989). How do self-attributed and implicit motives differ? Psychological Review, 96 (4), 690-702.

McClelland, D. C. (1995). Achievement motivation in relation to achievement-related recall, performance, and urine flow, a marker associated with release of vasopressin. Motivation \& Emotion, 19, 59-76

Murray, H. A. (1938). Explorations in personality: a clinical and experimental study of fifty men of college age. Oxford: Oxford University Press.

Murray, H. A. (1943). Thematic Apperception Test. Cambridge, Massachusetts: Harvard University Press.

Pavelková, I. (1997). Motivace žáků na konci ZŠ a na začátku SŠ z pohledu žáků a učitele. In Kantor, M., Výchova a vzdělávání v českých zemích na prahu třetího tisíciletí (pp. 79-84). Plzeň: PedF ZČU. [The motivation of pupils at the end of primary school and the beginning of high school from the perspective of pupils and teachers. In M. Kantor. Education in the Czech country on the threshold of the third millennium].

Pilkiewicz, M. (1991). Model školskej triedy ako spoločenskej skupiny. Psychológia a patopsychológia diet'at'a, 26(1), 35-47. [Model of school class as a social group].

Schultheiss, O. C. \& Brunstein, J. C. (Eds.). (2010). Implicit Motives. New York, NY: Oxford University Press.

Smith, Ch. P., Atkinson, J. W., \& McClelland, D. C. (2002). Motivation and Personality: Handbook of Thematic Content Analysis. New York: Cambridge University Press.

Ward, E. A. (1997). Multidimensionality of Achievement Motivation among Employed Adults. The Journal of Social Psychology, 137 (4), 542-544.

Wigfield, A. \& Eccles, J. S. (Eds.) (2002). Development of Achievement Motivation. San Diego, CA: Academic Press.

Advised by Vincentas Lamanauskas, Šiauliai University, Lithuania

Received: January 31, 2014

Accepted: April 10, 2014
Ivana Poledňová

PhD., Researcher, Masaryk University, Faculty of Social Sciences, Department of Psychology, Joštova 10, 60200 Brno, Czech Republic.

E-mail: polednov@fss.muni.cz

Website: http://www.muni.cz
PhD., Assistant Professor, Masaryk University, Faculty of Arts, Institute of Psychology, Arna Nováka 1, 60200 Brno, Czech Republic.

E-mail: stranska@phil.muni.cz

Website: http://www.muni.cz 